\title{
KAJIAN FILOSOFIS KARAKTERISTIK WIRAUSAHA URANG SUNDA
}

Oleh :

Dedeng Abdul Gani Amruloh

Program Studi Manajemen, STIE DR. KHEZ. Muttaqien

dedeng@stiemuttaqien.ac.id

DOI Artikel : https://doi.org/10.34308/eqien.v6i2.101

\begin{tabular}{l} 
Article Info \\
\hline Article History: \\
Received 08 Agustus 2019 \\
Accepted 22 Agustus 2019 \\
Available Online 09 September \\
2019
\end{tabular}

Keyword :

Sundanese, Sundanese

Philosophy, Entrepreneur

Characteristics

\section{PENDAHULUAN}

Wirausaha memegang peranan penting dalam kemajuan dan pembangunan suatu Negara, dimana salah satu indikatornya adalah ketika di populasi wirausaha di negara tersebut mencapai $2 \%$ dari populasi penduduknya. Data yang dirilis oleh Himpunan Pengusaha Muda Indonesia (http://www.suara.com/bisnis/2016/05/09/ 133306) menyatakan bahwa wirausaha di Indonesia pada tahun 2016 adalah 1,5 persen pengusaha dari sekitar 252 juta penduduk Indonesia. Artinya untuk mencapai tarap minimum jumlah wirausaha Indonesia masih membutuhkan sekitar 1,7 juta wirausahawan untuk mencapai angka dua persen. Diperlukan pendekatan, kajian dan studi mendalam dalam upaya meningkatkan jumlah dan kualitas wirausaha yang dimiliki Bangsa Indonesia untuk mendorong pembangunan bangsa ini kedepan. Salah satu pendekatan yang dapat dikembangkan untuk mendorong pengembangan kewirausahaan adalah penguatan motivasi dalam diri seseoroang untuk menjadi wirausahawan dengan menggunakan stimulus sistem nilai dan budayanya.

Pendekatan konseptual dan empirik dimungkinkan untuk mengkorealasikan 
antara budaya dengan kewirausahaan, pendekatan ini sejalan dengan argumentasi dan pandangan bahwa kewirausahaan merupakan ranah kajian sosial dan fenomena sosial (Steyaert, 2007). Argumentasi lain dalam pendekatan keilmuan kewirausahaan menyatakan bahwa faktor personal seseorang seperti sifat, sikap dan perilaku berhubungan erat dengan kewirausahaan, dimana setiap individu memiliki motivasi untuk mencari kesempatan ekonomi yang baru dengan usaha sendiri sampai dengan mendirikan organisasi bisnis, disamping faktor-faktor internal dan eksternal lainnya (Thornton PH. dkk, 2011); (Guzman \& Santos, 2001). Berdasarkan argumentasi di atas menegaskan bahwa kewirausahaan merupakan ranah keilmuan yang terbuka tidak terbatas pada keilmuan ekonomi tetapi termasuk juga keilmuan sosial, budaya dan psikologi karena termasuk didalamnya kajian tentang kepriabdian seseorang. Keterkaitan antara faktor ekonomi yang secara eksplisit mempengaruhi kewirausahaan tidak terlepas dari adanya faktor-faktor penentu lain. Salah satu faktor yang perlu pertimbangan aspek sosial dan budaya dalam aktifitas kewirausahaan (Drakopoulou Dodd \& Anderson, 2007). Pandangan ini sejalan dengan pendapat bahwa perilaku seorang wirausaha dalam proses bisnisnya tidak terlepas dari kepentingan dan pilihan mana yang lebih penting dari dirinya, dan perilaku individu selalu terkait dengan struktur sosial dan tata cara transaksi-transaksi ekonomi yang dilakukannya (Zhou, 2004).

Menjadi penting kemudian adalah adanya kajian secara mendalam tentang kewirausahaan dan latar belakang sosial dan budaya untuk menjadi dasar pengambilan kebijakan pengembangan kewirausahaan. Bangsa Indonesia yang dikenal karena keragaman suku bangsa dan budaya adalah potensi luar biasa yang jika pengembangan kewirausahaan dikembangkan dari sisi budaya diharapkan mampu mendorong dan meningkatkan motivasi warga Negara untuk menjadi wirausahawan. Pendekatan budaya dalam kewirausahaan telah banyak dilakukan dalam berbagai penelitian konseptual dan empiris, seperti keterkaitan antara nilai budaya dengan perilaku individu (Hofstede 2001; Hayton \& Calciotti, 2014; Thorntone dkk, 2011), dalam penelitiannya dijelaskan bahwa latar belakang budaya seseorang dalam mempengaruhi motivasi dan aktifitas wirausaha. Penelitian lain yang sejalan dengan konsepsi tersebut adalah pendapat bahwa perbedaan aktifitas kewirausahaan dapat dijelaskan melalui faktor budaya dan agama seseorang dan kondisi sosial merupakan faktor pendorong motivasi berprestasi yang membuat seseorang beraktifitas wirausahawan (McClelland, 1987) dalam Thomas and Muller (2000). Budaya dalam konteks penelitian ini diartikan sebagai bentuk pemrograman berpikir kolektif yang membedakan satu kelompok dengan kelompok lainnya dan bagaimana kelompok tersebut mampu merespon lingkungannya, dalam nilai, keyakinan, dan perilaku yang diharapkan secara umum dalam kelompok masyarakat dari wilayah geografis tertentu (Hofstede, 2001; Hayton, 2014).

Penelitian ini fokus kajian adalah budaya Sunda sebagai sistem nilai dan latar belakang urang Sunda yang membentuk karakteristik khas urang Sunda dalam melakukan aktifitas wirausaha. Etnis atau Sunda di Indonesia merupakan suku terbesar kedua di Indonesia dengan populasi sebesar 36,7 juta jiwa atau 15,5 persen dari total selurung penduduk Indonesia yang populasinya 236,7 juta (BPS, 2010). Jika melihat data statistik tersebut suku Sunda terbilang besar dan potensial jika dikaitkan dengan program pengembangan kewirausahaan, kondisi ini menjadi permasalahan karena secara tradisional etnis Sunda tidaklah dikenal sebagai etnis wirausahawan, berbeda dengan etnis Minangkabau dan Bugis, walapun demikian bukan berarti tidak ada sama sekali orang Sunda yang menjadi wirausahawan dan sukses dalam bisnis 
bahkan sampai ditingkat dunia. Salah satu aspek budaya yang mencerminkan sistem nilai, falsafah hidup dari suatu etnis atau kelompok masyarakat adalah budaya lisan, perilaku dan hasil karya dan karsa masyarakat tersebut. Budaya lisan pada etnis Sunda sangat beragam dan dalam rauang lingkup yang luas, dari budaya lisan kemudian secara turun temurun menjadi pemahaman bersama urang Sunda dan dijadikan pakem yang diwujudkan dalam aktifitas keseharian, seperti aturan dan etika pergaulan (Didin Komarudin, 2016). Falsafah hidup yang dijadikan panduan turun temurun urang Sunda melalui budaya lisan dan masih ada hingga sekarang merupakan ciri budaya yang dapat dijadikan dasar bagi kajian yang lebih komprehensif untuk menggali keterkaitan antara budaya Sunda dengan karakteristik dan perilaku wirausaha urang Sunda.

Dengan demikian tujuan dari penelitian ini adalah untuk membentuk kerangka konseptual yang mengintegrasikan antara budaya Sunda yang direprentasikan melalui budaya lisan yang ada dimasyarakat Sunda dengan kerangka konsep karakteristik wirausaha. Hasil yang diharapkan dari penelitian ini adalah karakteristik wirausaha urang Sunda. Metode penelitian yang digunakan adalah deskriptif kualitatif berbasis penelitian kepustakaan yang bersumber dari jurnal, majalah, dan sumber lainnya yang relevan dan melakukan wawancara terbatas yang relevan dengan tujuan penelitian. Luaran dari penelitian ini selain adanya kerangka konseptual karakteristik wirausaha urang Sunda yang mendasari penelitian yang lebih komprehensif dan empiris tentang falsafah dan nilai budaya yang membentuk karakteristik wirausaha urang Sunda, yang dihubungkan dengan motivasi dan kesuksesan atau kinerja wirausahanya.

\section{KAJIAN PUSTAKA DAN PEGEMBANGAN HIPOTESIS \\ Kewirausahaan dan Kewirausahaan Berbasis Etnik}

Kewirausahaan sebagai istilah dipublikasikan oleh ilmuan-ilmuan Francis pada abad $17-18$ Masehi seperti Richard Cantillon dan JB. Say (Abad 19 Masehi) yaitu entreprendre yang diterjemahkan dalam bahasa Inggris menjadi entrepreneur yang dapat diartikan sebagai seseorang yang memulai atau "someone who undertake" dan memiliki kemampuan membentuk organisasi busnis yang baru (Shane and Venkataraman, 2000; Hoque dkk, 2014). Istilah kewirausahaan kemudian berkembang dan menjadi lapangan ilmu tersendiri yang terus menerus diteliti dan ditelaah dari berbagai sudut pandang dan pendekatan hingga sekarang. Kewirausahaan sering kali diidentikan dengan seseorang yang memulai usaha karena sifat orang tersebut yang inovatif dan mampu menciptakan peluang, mengelola organisasi untuk memperoleh keuntungan dengan cepat (Drucker, 2014). Istilah kewirausahaan kemudian berkembang dan menjadi lapangan ilmu tersendiri yang terus menerus diteliti dan ditelaah dari berbagai sudut pandang dan pendekatan hingga sekarang.

Pendekatan kajian kewirausahaan yang berkembang sampai dengan sekarang adalah pendekatan psikology yang dikenal sebagai teori sifat dan perilaku wirausaha. Teori sifat dan perilaku wirausaha menjelaskan tentang karakteristik wirausaha yang dimiliki seorang wirausaha, sifat dan perilaku wirausaha adalah hal yang berbeda tetapi saling berkaitan (Rauch \& Frese, 2007), sifat seseorang adalah pembeda antara seorang wirausaha dan lainnya, sifat merupakan pendukung perilaku wirausaha dan lebih penting untuk dikaji adalah perilaku wirausaha. Berdasarkan kosepsi karakteristik atau personal dan perilaku kewirausahaan dalam konteks penelitian ini adalah latar belakang seseorang yang membentuk karakteristik dan perilakunya dalam wirausaha, seperti sistem nilai, budaya, agama, struktur sosial dan gender dan lainnya. 
Kajian kewirausahaan mengalami perkembangan yang cepat melalui penelitian konseptual dan empiris adalah kewirausahaan berbasis etnis (ethnic entrepreneurship). Konsepsi ini merupakan ranah kajian wirausaha berkembang dari fenomena bisnis-bisnis yang dilakukan oleh minoritas pendatang yang berkembang di negara-negara maju, dimana bisnis ini dilakukan oleh sekelompok orang yang memiliki ciri khas tertentu yang berbeda secara phisik, biologis dan asal usul (ras). Portes dan Jensen (1987) mendefinisikan etnik ekonomi sebagai usaha yang dimiliki dan diopersionalkan oleh etnis tertentu, dan anggota bisnis tersebut berasal dan memiliki budaya dimana dia berasal. Etnisitas dalam kewirusahaan merupakan hasil perilaku simultan pemilik dan pengelola usaha dari bisnis mereka sendiri yang pada dasarnya kelompok bisnis tersebut selalu terkait dengan warisan budaya umum atau asal usulnya (Wang, 2013; Zhou, 2004). Etnisitas dalam kewirausahaan dapat dilihat dari sudut pandang usaha dan aktivitas ekonomi dalam ruang lingkup terbatas, dan dalam ruang lingkup lingkungan keluarga etnis tersebut (Menzies, dkk. 2007). Perilaku seorang wirausaha dalam proses bisnisnya selalu terkait dengan struktur sosial yang ada di masyarakat sekitarnya, struktur sosial dan masyarakat dan tata cara transaksi-transaksi ekonomi yang dilakukannya (Zhou, 2004).

\section{Budaya dan Kewirausahaan}

Etnis atau Suku Bangsa merupakan sekelompok sosial masyarakat yang mengidentikan diri berdasarkan persamaan yang diwariskan secara turun menurun dan diakui kesamaan tersebut dalam bentuk bahasa, budaya, agama, perilaku dan ciriciri biologisnya. Sedangkan budaya merupakan suatu pengetahuan dimana masyarakat menggunakan pengalamannya untuk menghasilkan suatu sikap diri dan perilaku sosial, disisi lain budaya merupakan sekumpulan pengetahuan, kepercayaan, seni, moral, hukum, adat dan kebiasaan yang diperoleh sebagai anggota sebuah perkumpulan atau komunitas tertentu (Luthan, 2012; I Gede Riana, 2011).

Permasalahan mendasar dalam kajian budaya dan kewirausahaan adalah terletak pada belum adanya kesepakatan bersama tentang definisi budaya itu sendiri (Hayton dkk, 2002; Thornton, 2011). Walapun demikian kajian budaya dalam konteks kewirausahaan yang relevan dan sering digunakan dalam penelitian kewirausahaan adalah dimensi nilai budaya dari Hofstede (2001) dimana nilai budaya didefinisikan sebagai pemrograman pikiran kolektif yang membedakan anggota dari sekelompok masyarakat dengan kelompok lainnya dan bagaimana mereka merespon perubahan lingkungannya (Thornton, dkk. 2011, Hayton \& Calciotti, 2014).

Etnisitas dan budaya merupakan merupakan latar belakang sosial seseorang yang membentuk perilaku kesehariannya dan memiliki perbedaan spesifik dengan orang dari latar belakang etnis dan budaya yang berbeda. Perbedaan ini memiliki dampak pada pilihan bisnis dan wirausaha, hasil studi pada penelitian-penelitian terdahulu menunjukan adanya keterkaitan antara kewirausahaan atau aktifitas bisnis dan ekonomi dengan latar belakang sosial seseorang, perbedaan lingkungan seseorang yang berakibat pada perbedaan kondisi politik, sosial, ekonomi dan teknologi memiliki relevansi dengan pilihan bisnis dan kewirausahaan (1993, Thornton, dkk, 2011).

Heyton dkk (2002) berdasarkan kajian literature mereka menegaskan tentang hubungan budaya dengan kewirausahaan dalam tiga ranah besar yaitu fokus kajian pertama pada pengaruh budaya nasional/regional terhadap budaya inivasi dan pembentukan bisnis, kedua fokus pada hubungan antara budaya nasional dengan karakteristik individual wirausaha dan ketiga dampak budaya nasional terhadap wirausaha perusahaan (Thornton, dkk, 2011; Hayton and Calciotti, 2014). Berdasarkan konsepsi di atas yang menjadi 
fokus perhatian dalam penelitian ini adalah bagaimana pengaruh budaya terhadap karakteristik individual wirausaha.

\section{Motivasi wirausaha}

Seorang individu melakukan sesuatu tidak terlepas dari keingina, arah dan persitensi dirinya dalam mencapai tujuan (Robbins \& Coulter, 2012), tentu saja termasuk seseorang yang memilih bekerja sediri atau menjadi wirausahawan. Motivasi dalam kajian kewirausahaan merupakan bagian penting yang tidak dapat dipisah, motivasi pada dasarnya adalah ranah keilmuan Pshicologi yang diterapkan dalam organisasi dan memainkan peranan penting dalam pembentukan organisasi baru (Herron and Spienza, 1992). Motivasi berperan dalam membentuk sifat dan sikap wirausaha serta bagaimana motivasi tersebut mempengaruhi hasil usaha, seseorang memiliki pilihan untuk bekerja atau memilih menjadi pekerja mandiri hal ini tidak terlepas dari intensi untuk menjadi wirausaha dan bagaimana sikapnya terhadap kesiapan menanggung resiko (Segal, dkk, 2005).

Motivasi berwirausaha tidak terlepas dari faktor internal dalam diri seseorang. Motivasi wirausaha tidak terlepas dari peluang yang muncul disekitarnya dan kebutuhan akan kehidupan yang lebih baik Xavier-Oliviera, dkk (2015). Walaupun demikian motivasi wirausaha bukanlah sekedar memanfaatkan peluang dan memenuhi kebutuhan hidup tetapi hubungan interkoneksi yang kompleks antara keadaan sekitar individu dan keputusan-keputusan bisnis, pilihan seseorang untuk menjadi wirausaha lebih ditentukan oleh motivasi untuk dapat lebih bersifat otonom dan harapan bekerja lebih baik, adanya peluang dan tantangan, alasan finansial dan faktor keluarga dan turunan (Stephan, et.al. 2015). Pilihan seseorang untuk menjadi wirausahawan berbedabeda, pilihan utama biasanya karena manfaat dari pilihan pilihan tersebut yang didorong oleh adanya harapan untuk terus tumbuh, alasan lain yang menentukan pilihan seseorang untuk menjadi wirausaha adalah daya tahan usaha dan kesuksesan bisnis. Konsepsi motivasi wirausaha dari sudut pandang klasik yaitu teori faktor pendorong (push factor) dan faktor penarik (pull factor), motivasi wirausaha bergeser kearah post-materialime yang berarti keuntungan ekonomi bukan merupakan faktor penarik utama tetapi lebih kepada faktor dilur itu seperti nilai budaya dan ajaran agama (Tlaiss, 2015).

\section{Budaya dan Karakter Wirausaha}

Hopstede (2001), secara menemukan hipotesis keterkaitan antara budaya dan kewirausahaan, hasil studinya menyatakan bahwa kewirausahaan dipengaruhi secara kuat oleh kecenderungan budaya masyrakat individualistis dan budaya maskulinitas. Nilai budaya masyarakat yang menghindari ketidak pastian memiliki pengaruh yang lemah terhadap kewirausahaan (Hayton, dkk. 2002; Thornton, dkk, 2011; Hayton and Calciotti, 2014). Secara parsial budaya yang menggambarkan sikap atau kecenderungan sikap seorang wirausaha yang seperti keinginan berprestasi, kesiapan menanggung resiko dan inovatif, memiliki keterkaitan erat dengan budaya yang melatar belakangi seorang wirausahawan (Hayton and Calciotti, 2014).

Nilai budaya dengan sifat dan perilaku seorang wirausaha memiliki hubungan yang erat. Sifat individual wirausaha merupakan karakteritik kepribadian seorang wirausaha yang menjadi pembeda dirinya dengan orang yang bukan wirausaha. Berbagai penelitian telah menganalisa ciri-ciri kepribadian tertentu sebagai karakteristik pengusaha. Misalnya, dalam studi oleh Entrialgo et al. (2000) locus of control, motivasi berprestasi dan toleran terhadap ambigutas dianggap sebagai penentu kecenderungan untuk berwirausaha. Sedangkan studi Stewart et al. (1998), menggambarkan sifat seorang wirausaha adalah kebutuhan untuk pencapaian, kecenderungan mengambil risiko, dan inovasi (Yonce Gurol \& Nuray 
Atsan, 2006). Sedangkan Thomas and Muller (2000) melakukan penilaian terhadap sifat individu wirausaha yaitu inovatif, locus of control, kecenderungan terhadap resiko dan energy, karakteristik tersebut secara umum memiliki keterkaitan yang erat dengan budaya. Hasil penelitian lain, menggambarkan wirausaha adalah orang yang cenderung toleran terhadap situasi ambigu, mandiri, otonom, ingin berbeda, tidak memiliki kepentingan sosial, menikmati pengambilan risiko, siap beradaptasi dengan perubahan, dan memiliki kebutuhan dukungan yang kecil dari orang lain (Hayton and Calciotti, 2014).

\section{Falsafah Urang Sunda}

Falsafah diterjemahkan secara bebas sebagai pandangan hidup, atau landasan dasar bagi seseorang atau sekelompok orang untuk menjalani kehidupan (dan juga tentang mati). Makna tersebut lebih sempit dari makna kata filsafat sebagai kata dasar dari falsafah, yang dimaknai sebagai metode berpikir secara kritis dan rasional, sistimatis mengenai keadaan umum dunia, pembenaran atas kepercayaan serta cara hidup sehari-hari. Konsekwensi dari filsafat adalah masyarakat yang memiliki tradisi berpikir untuk berpikir yang diwujudkan dalam tradisi menulis, dalam kenyataanya sangat sedikit terjadi pada masyarakat Sunda sehingga yang menonjol dalam kajian falsafah urang Sunda adalah tradisi lisan sebagai sumber utama. Tradisi lisan mengandung resiko kemungkinan kesalahan arti dan persepsi terhadap nilai kearifan hidup yang terkandung dalam papatah yang diturunkan kepada setiap generasi urang Sunda tersebut. Kearifan hidup yang diturunkan karuhun urang Sunda sangat mungkin semakin berkurang dari sisi jumlah dan makna karena tidak diimbangi dengan tradisi tulis, dan dari generasi kegenerasi berikutnya tidak disampaikan secara utuh, dan tanpa penjelasan makna yang sesungguhnya.

Urang Sunda diartikan sebagai orang yang mengaku dirinya dan diakui oleh orang lain sebangai orang Sunda, yang memilki kriteria asal usul atau hubungan darah orang tua Sunda dan kriteria sosial budaya yang dimaknai urang Sunda adalah orang yang dibesarkan dalam lingkungan sosial budaya Sunda (Edi S. Ekajati, 2014). Dengan demikian yang dimaksud dengan falsafah urang Sunda adalah nilai kearifan hidup nenek moyang Sunda yang diturunkan dari generasi kegenarasi melalui tradisi tulisan dan lisan yang masih digunakan oleh urang Sunda sampai dengan sekarang sebagai pandangan hidup.

Falsafah sebagai sistem nilai dan pandangan hidup yang digariskan karuhun Sunda yang menjadi landasan bagi Budaya urang Sunda, berdasarkan pendapat $\mathrm{H}$. Hasan Mustofa (1852-1930) dalam artikel H. Wawan "Hawe" Setiawan menyatakan bahwa sistem nilai yang budaya Sunda berdasarkan pada pandangan: "geus pageuh pisan adatna urang sunda ngukuhan kana babasan nini akina, pokna: ciri sabumi cara sadesa, pangasuhna indung hukumna bapa darigama". Pandangan ini dapat diartikan bahwa pandangan hidup orang sunda tidak terlepas dari pendahulu (karuhun) dimana perilaku urang Sunda tidak boleh terlepas dari aturan budaya dan agama. Konsepsi ini menegaskan pandagan hidup urang Sunda yang dikenal dengan "Sineger Tengah" yang diartikan keseimbangan dalam segala aspek kehidupan agar selalu wajar dan seimbang. Falsafah tersebut merupakan dasar pembentuk budaya Sunda sebagai hasil karya, karsa dan cipta urang Sunda (Rieza D. Dienaputra, 2011) yang kemudian budaya tersebut mendorong sifat, sikap dan perilaku anggota masyarakatnya.

Dalam konteks penelitian ini adalah falsafah dan nilai budaya urang Sunda yang berkaitan dengan karakteristik wirausaha dan memiliki makna untuk me-motivasi urang Sunda untuk menjadi wirausahawan, terlepas dari tepat dan tidaknya dalam memaknai nilai kearifan kehidupan karuhun Sunda yang diturunkan dalam tradisi tulisan dan lisan yang diperoleh dari berbagai sumber kajian ini. 
Potensi besar yang dimiliki Indonesia dengan keberagaman suku bangsa tersebut kajian kewirausahaan menjadi penting yang berkaitan dengan program peningkatan jumlah wirausahawan yang diinginkan pemerintah melalui pendekatan budaya. Urang Sunda yang secara tradisional tidak dikelnal sebagai etnis wirausaha di Indonesia adalah salah satu suku potensial yang dapat ditingkatkan kemampuan wirausahanya hal ini didasarkan pada sistem nilai dan falsafah urang Sunda sendiri yang secara implisit dapat dimaknai sebagai dorongan untuk menjadi wirausahawan. Pandangan ini didasarkan pada intrepretasi budaya tutur urang Sunda yang telah lama menjadi panduan dasar perilaku urang Sunda yang jika difahami dan diterapkan dapat menjadi dasar pembentukan konsepsi diri dan karakteristik urang Sunda yang sama dengan karakteristik utama dalam konsep sifat, sikap dan perilaku wirausaha.

\section{FALSAFAH KEWIRAUSAHAAN URANG SUNDA}

\section{Falsafah Pembentuk Karakter Wirausaha}

Falsafah Sunda yang secara turun temurun menjadi dasar karakter dan perilaku urang Sunda dalam menjalankan aktifitas diberbagai bidang kehidupan yang pertama adalah ungkapan cageur, bageur, bener, pinter, d an singer. Kata Cageur mengandung arti sehat jasmani dan rohani dan secara mendalam kata ini dapat dimaknai sebagai karakter masyarakat yang mampu berfikir rasional dan proporsional dengan dilandasi nilai moral. Bageur berarti berperilaku baik, sopan santun, ramah, bertata krama, karakter ini menggambarkan urang Sunda adalah masyarakat yang memiliki sifatsifat kemanusiaan, menjunjung akhlak mulia terhadap sesama. Bener yaitu jujur, amanah dan penyayang, bageur dapat dimaknai sebagai karakteristik masyarakat yang senantiasa amanah, tidak berbohong, tidak berkhianat, dan menunjung tinggi integritas yang artinya tiap ucapan harus sesuai dengan tindakan. Pinter, dimaknai sebagai orang yang memiliki ilmu pengetahuan, karakteristik pinter digambarkan sebagai masyarakat yang berilmu dan selalu menggunakan ilmu dalam setiap perilakunya untuk kepentingan dunia dan akhirat. Terakhir Singer artinya mawas diri dan sering juga didentikan dengan "cerdas" serta kratif dan inovatif, kata ini dimaknai sebagai masyarakat yang memiliki karakteristik toleran, senang berkorban/mendahulukan kepentingan orang lain, senang menerima kritikan/masukan dari orang lain terhadap dirinya untuk dijadikan bahan refleksi diri, serta memiliki rasa kasih sayang terhadap sesama.

Filosofi utama yang menjadi dasar pembentuk karakter urang Sunda adalah "silih asah, silih asih, silih asuh", nilai kearipan lokal ini mencerminkan karakter urang Sunda yang selalu saling menyokong satu sama lain dengan landasan kasih sayang dan rasa saling memiliki. Makna yang terkandung dalam filosofi adalah penting untuk urang Sunda selalu mengasah potensi diri dan membantu sesama dalam mengembangkan potensinya, untuk hasil kinerja yang maksimal. Makna "silih" yang berarti saling dalam filosofi ini dimaknai bahwa urang Sunda dalam melakukan suatu pencapaian haruslah membawa kebermanfaatan bagi sesama dan mampu menjadi motivasi untuk dapat bersamasama meraih keberhasilan. (https://nasisangu.wordpress.com/2013/07/04/ enkulturisasi-karakteristik-cageur-bageurbener-singer-pinter/).

\section{Karakteristik Wirausaha Utama urang Sunda}

Falsafah Sunda yang diturunkan dari generasi kegenerasi urang Sunda melalui berbagai macam metode seperti budaya lisan (tutur) adalah faktor pembentuk karakteristik personal urang Sunda termasuk perilaku urang Sunda dalam kewirausahaan, karakteristik wirausaha urang Sunda yang dibentuk melalui falsafah Sunda antara lain:

\section{a. Kepemimpinan yang kuat}

Kewirausahaan tidak terlepas dari kemampuan kepemimpinan seseorang dalam memimpin perusahaannya, yaitu pemimpin yang mampu melihat peluang, menciptakan visi dan memobilisasi sumber daya kunci untuk mencapai visi dan kepentingan berbagai stakeholder serta mampu menciptakan nilai (Leitch and Volery, 2017). Tipe pemimpin Sunda adalah orang yang memiliki karakteristik 
optimis, karismatis, meyakinkan dan konsisten. Karakter kepemimpinan urang Sunda ini dibentuk oleh ujaran lain: "kudu hade gogog hade tagog", yaitu pemimpin yang memiliki keseimbangan antara biacara dengan penampilan yang meyakinkan, optimistik, dan karismatik. Ujaran "nyaur kudu diukur, nyabda kudu diungang", yaitu pemimpin harus menjaga ucapan, tindakan atau perbuatan agar tidak menyakiti orang. Ujaran "batok bulu eusi madu", yaitu tipe pemimpin yang harus memiliki keahlian atau kecerdasan yang baik. Ujaran "ulah bengkung bekas nyalahan", yaitu pemimpin yang cermat dalam mengambil keputusan, jangan salah berbuat karena hasilnya akan sia- sia atau hasilnya tidak akan baik

\section{b. Inovatif dan kreatif}

Karakteristik personal seorang wirausaha yang penting adalah kreatif dan inovatif. Karakteristik ini semestinya dimiliki oleh urang Sunda, dasar filosofi dari kata "singer" digambarkan sebagai orang berbuat tanpa disuruh dan mengendalkan kecerdasan dalam berbuat. Dalam tradisi lisan karakteristik yang menggambarkan sifat ini yaitu "mun teu ngoprek moal nyapek, mun teu ngakal moal ngakeul, mun teu ngarah moal ngarih, yang memiliki makna sama yaitu berusaha untuk memperoleh sesuatu. Ujaran lisan seperti "tungkul $\mathrm{ka}$ jukut tanggah $\mathrm{ka}$ sadapan" juga bermakna tidak akan makan/memperoleh rizki jika tidak kreatif, inovatif dan mau bekerja keras.

\section{c. Berani mengambil resiko}

Karakter utama wirausaha adalah berani mengambil resiko. Urang Sunda secara tradisi dimungkinkan untuk memiliki karakter ini, ujaran lisan sebagai dasar pembentuk karakter wirausaha berani mengambil resiko adalah "ulah kumeok memeh dipacok" yang bermakna berani dan siap menngambil resiko atau tidak menyerah sebelum dilakukan. Ujaran "sacangreud pageuh sagolek pangkek", memiliki makna relative sejalan dengan pengambilan resiko atas apa yang dilakukan, yaitu bermakna siap menepati janji dan konsisten dengan apa yang diucapkan dan dijanjikan.

\section{d. Berfikir positif dan Konsisten}

Secara konseptual karakteristik sifat wirausaha adalah selalu berfikir positif dan konsisten. Pepatah karuhun yang mendorong urang Sunda memiliki karakteristik wirausaha seperti itu adalah "ulah lunca linci luncat mulang, udar tina tali gadang, ulah lali tina purwadaksina" yang bermakna selalu mengikuti etika dan kebiasaan yang baik, Ungkapan "ulah cueut ka nu hideung ulah ponteng koneng, yang sama dengan ujaran " $n u$ lain kudu dilainkeun, nu enya kudu dienyakeun, $n u$ ulah kudu diulahkeun" yaitu konsisten dengan kebenaran dan katakan salah bila salah, katakan benar kalau memang benar. Ujaran lisan"ulah elmu ajug", yang dapat dimaknai adanya konsistensi antara arahan dengan tindakan. "Ulah gindi pikir belang bayah", yang bermakna jangan berfikir negatif dan menilai orang lain dengan negative tetapi harus dalam kacamata positif. Ungkapan "kudu leuleus jeujeur liat tali" memiliki makna yaitu hidup itu harus kuat memegang prinsip, menanggung beban sebarat apapun dan jangan menyerah.

\section{e. Fleksibel dan Toleran}

Karakteristik dominan yang lain yang mendorong wirausaha adalah sifat fleksibel dan toleran. Sifat urang Sunda yang dapat mendorong perilaku wirausaha yaitu fleksibel dan toleran diajarkan dalam bahasa tutur seperti "kudu bisa ka bala ka bale" yang dapat dimaknai bahwa urang Sunda harus bersifat adaptif dan fleksible. Ungkapan "ulah muragkeun duwegan ti luhur, ulah cacag nangkaeun", ulah puraga tanpa kateda" yang juga dimaknai bahwa urang Sunda tidak boleh melakukan yang tidak perlu, melakukan sesuatu dengan setengah hati dan berbuat asalasalan. Selain itu sifat yang diajarkan melalui ujaran "bobot pangayon timbang taraju, yang dimaknai sebagai dasar melakukan suatu tindakan harus difirkan dengan matang, objektif dan seusuai dengan seharusnya.

Berdasarkan uraian di atas pada dasarnya urang Sunda sudah memiliki akar tradisi untuk menjadi wirausahawan, atau setidaknya teleh turun menurun diajarkan sifat-sifat dasar yang dapat mendasari karakteristik pribadi seorang 
wirausaha. Pertanyaan mendasar selanjutnya adalah benar tidaknya seorang wirausaha beretnis Sunda yang sukses itu didasari oleh kekuatan dirinya memegang tradisi urang Sunda, atau karena faktor yang lain. Diperlukan adanya kajian yang lebih mendalam untuk menjawab pertanyaan tersebut. Pertanyaan mendasar lainnya adalah benar dan tidaknya pemaknaan tradisi lisan tersebut untuk pembentuk karakteristik wirausaha urang Sunda, karena selama ini tradisi lisan tersebut tidak dikhususkan untuk mendorong seseorang menjadi wirausahawan.

Pendekatan budaya dalam wirausaha sudah banyak dilakukan dalam berbagai penelitian dengan hasil yang beragam, secara umum dari penelitian-penelitian tersebut secara konsisten di temukan adanya hubungan antara budaya nasional/regional dan etnik tertentu dengan kewirausahaan, dengan dasar tersebut perlu ada upaya lebih yang harus dilakukan oleh para pemangku kepentingan pengembangan dan pemberdayaan kewirausahaan khususnya di ruang lingkaup masyarakat etnis Sunda mengingat potensi jumlah etnis Sunda dan perubahan kondisi lingkungan ekonomi dan sosial yang secara umum mendorong urang Sunda untuk menjadi wirausahawan. Salah satu tawaran konseptual tentang upaya tersebut adalah dengan pendekatan budaya Sunda, yang pada dasarnya sistem nilai dan falsafah yang ada di dalamnya sudah ada indikasi mendorong urang Sunda untuk menjadi wirausahawan, untuk memastikan hal tersebut maka diperlukan suatu penelitian yang mendalam dan komprehensif .

\section{HASIL DAN PEMBAHASAN}

Pendekatan budaya dalam wirausaha sudah banyak dilakukan dalam berbagai penelitian dengan hasil yang beragam, secara umum dari penelitian-penelitian tersebut secara konsisten di temukan adanya hubungan antara budaya nasional/regional dan etnik tertentu dengan kewirausahaan. Pemikiran tersebut adalah dasar berfikir untuk perlu ada upaya lebih yang harus dilakukan oleh para pemangku kepentingan pengembangan dan pemberdayaan kewirausahaan khususnya di ruang lingkaup masyarakat etnis Sunda, mengingat potensi jumlah etnis Sunda yang sangat besar dan ditambah dengan potensi lingkungan tempat tinggal masyarakat Sunda, serta perubahan kondisi lingkungan ekonomi dan sosial yang secara umum mendorong seseorang untuk menjadi wirausahawan. Salah satu tawaran konseptual tentang upaya meningkatkan wirausaha urang Sunda adalah dengan pendekatan budaya Sunda. Pendekatan ini didasari oleh pemikiran bahwa pada dasarnya sistem nilai dan falsafah yang ada di dalam budaya Sunda ada indikasi mendorong urang Sunda untuk menjadi wirausahawan. Untuk memastikan pendapat ini maka kemudian diperlukan adanya penelitian ilmiah yang lebih mendalam dan komprehensif.

Kerangka dasar berfikir lain adalah anggapan bahwa urang Sunda dikenal dengan masyarakat religious yang memegang teguh Agama dan tradisi Sunda sebagai panduan kehidupan sehari-harinya. Kerangka tersebut perlu pula ditelaah secara mendalam dalam bentuk penelitian yang menguji hubungan antara niai agama atau spiritualitas, nilai budaya pada karakteristik wirausaha serta pengaruhnya terhadap kesuksesan wirasuaha seseorang yang berlatar belakang etnis Sunda.

\section{REFERENSI}

Aldrich, H. E. and R. Waldinger, 1990 "Ethnicity and Entrepreneurship," Annul Review of Sociology, 16:111135.

Amruloh, D.A.G., 2016. Kontruksi Hubungan Orientasi Wirausaha dengan Kinerja USAha (Studi Kasus pada UMKM Keramik Plered Purwakarta). Eqien: Jurnal Ekonomi dan Bisnis, 3(1), pp.2329.

Badan Pusat Statistik
$\begin{aligned} & \text { Kewarganegaraan, } \\ & \text { Bangsa,Agama, dan }\end{aligned}$ Buku
Sehari-hari Penduduk Indonesia,
ISBn: 978-979-064-417-5 no.
Publikasi: 04000.1110,Katalog
BPS: 2102032


Didin Komarudin (2016) Bisnis Orang Sunda (Studi Teologi dalam Etika Bisnis Orang Sunda), el Harakah Vol.18 No.1 ejournal.uinmalang.ac.id

Drakopoulou Dodd, S., \& Anderson, A. R. (2007). Mumpsimus and the mything of the individualistic entrepreneur. International Small Business Journal, 25(4), 341-360.

Drucker, P., (2014). Innovation and entrepreneurship. Routledge.

Edi S. Ekadjati (2014) Kebudayaan Sunda, Suatu Pendekatan Sejarah, Dunia Pustaka Jaya, Bandung

Entrialgo, M., Fernandez, E. and Vazquez, C. (2000), "Characteristics of managers as determinants of entrepreneurial orientation: some Spanish evidence", Enterprise and Innovation Management Studies, Vol. 1 No. 2, pp. 187-205. In : Gurol Y and Atsan N, (2006), Entrepreneurial Characteristics Amongst University Student, Some Insight for Entrepreneurship Education and Training in Turkey, International Journal of Education and Training, Vol. 48, no. 1, Emerald Group Publishing Limited

Gurol Y and Atsan N, (2006), Entrepreneurial Characteristics Amongst University Student, Some Insight for Entrepreneurship Education and Training in Turkey, International Journal of Education and Training, Vol. 48, no. 1, Emerald Group Publishing Limited

Hayton JC, George G and Zahra SA (2002) National culture and entrepreneurship: A review of behavioural research. Entrepreneurship Theory and Practice 26(4): 33-52.
Hayton JC, and Calciotti G (2014) Is There an entrepreneurial culture ?: A review of empirical research, ERC Research paper, www.entreprise research.ac.uk

Herron, L. and Sapienza, H.J. (1992), "The entrepreneur and the initiation of new venture launch activities", Entrepreneurship Theory and Practice, Vol. 17 No. 1, pp. 49-55. In : Segal G, Dan Borgia and Schoenfeld, J (2005) International Journal of Entrepreneurial Behaviour \& Research Vol. 11 No. 1, 2005 pp. 42-57q Emerald Group Publishing Limited 13552554

DOI $10.1108 / 13552550510580834$

Hofstede G (2001) Culture's Consequences: Comparing Values, Behaviors, Institutions and Organizations across Nations, 2nd ed. Thousand Oaks, CA: SAGE.

https://books.google.co.id/books

Hoque, N., Mamun, A., \& Mohammad Ahshanul Mamun, A. (2014). Dynamics and traits of entrepreneurship: an Islamic approach. World Journal of Entrepreneurship, Management and Sustainable Development, 10(2), 128-142.

I Gede Riana (2011) Dampak Penerapan Kultur Lokal Tri Hita Karana terhadap Kewirausahaan dan Orientasi Pasar, Jurnal Teknik Industri, Vol. 13, No. 1, Juni 2011, 37-44 ISSN 1411-2485 print / ISSN 2087-7439 online

Leitch, C. M., \& Volery, T. (2017). Entrepreneurial leadership: Insights and directions. International Small Business Journal, 35(2), 147-156.

Luthans, F., (2012) Organizational Behavior An Evidence-Based Approach ,12nd edition, New York, Mc. Graw Hill, Inc., 
Menzies, TV, LJ Filion, GA Brenner and S Elgie (2007). Measuring ethnic community involvement: Development and initial testing of an index. Journal of Small Business Management, 45(2), 267-282.

Ma'mun, H.F. and Amruloh, D.A.G., 2019. Kreativitas dan Psychological Capital Pengusaha Batu Templek di Kabupaten Purwakarta. Eqien: Jurnal Ekonomi dan Bisnis, 6(1), pp.1-11.

Rauch, A., \& Frese, M. (2007). Born to Be an Entrepreneur? Revisiting the Personality Approach to Entrepreneurship.

Reiza D. Dienaputra (2011), Sunda : Sejarah, Budaya, dan Politik, Sastra Unpad Press

Robbins, Stephen P., Mary Coulter. Management 11th ed (2012). ISBN 978-0-13-216384-2 1., Pearson

Education,Inc.,publishing as Prentice Hall

Segal G, Dan Borgia and Schoenfeld, J (2005) International Journal of Entrepreneurial Behaviour \& Research Vol. 11 No. 1, 2005 pp. 42-57q Emerald Group Publishing Limited 1355-2554 DOI

$10.1108 / 13552550510580834$

Shane, S., \& Venkataraman, S. (2000). The Promise Of Entrepreneurship as a Field research, Academy of Management Review, 25(1), 217226.

Stephan U, Hart M, Mickiewicz T, Drews CD (2015), Understanding Motivations for Entrepreneurship, BIS Research paper no. 212, Aston Business School, Birmingham, UK \& IFF Research, London, UK

Steyaert, C. (2007). 'Entrepreneuring'as a conceptual attractor? A review of process theories in 20 years of entrepreneurship studies.
Entrepreneurship and regional development, 19(6), 453-477.

Thornton PH, Ribeiro-Soriano D and Urbano, D (2011), Socio-cultural factors and entrepreneurial activity: An overview, International Small Business Journal 29(2) 105-118, SAGE

Thomas, A. S., \& Mueller, S. L. (2000). A case for comparative entrepreneurship: Assessing the relevance of culture. Journal of International Business Studies, 31(2), 287-302. Orientasi

Tlaiss, Hayfaa A, (2015) Entrepreneurial motivations of women: Evidence from the United Arab Emirates, International Small Business Journal, Vol. 33(5) 562-581, (C) The Author(s) 2013 Reprints and permissions:

sagepub.co.uk/journalsPermissio ns.nav DOI: 10.1177/0266242613496662isb.s agepub.com

Wang, Q. (2013), Constructing a multilevel spatial approach in ethnic entrepreneurship studies, International Journal of Entrepreneurial Behavior \& Research, Vol. 19 Iss 1 pp. 97 113

Wawan "Hawe" Setiawan, H. (.....) Etika Sunda, http://file.upi.edu/Direktori/FPBS /JUR._PEND._BAHASA_DAER AH/HAWE_SETIAWAN/makal ah/Etika_Sunda.pdf., diunduh 11 Juli 2018 jam 4.27pm

Warnaen, Suwarsih, dkk. (1987) Pandangan Hidup Orang Sunda Seperti Tercermin dalam Tradisi Lisan dan Sastra Sunda. Bandung: Bagian Proyek Penelitian dan Pengkajian Kebudayaan Sunda (Sundanologi) Dirjen Kebudayaan Depdikbud, 
Xavier-Oliveira E, Laplume AO and Pathak S (2005), What motivates entrepreneurial entry under economic inequality? The role of human and financial Capital, human relations, Vol. 68(7) 1183-1207 Reprints and permissions:

sagepub.co.uk/journalsPermissio

ns.nav

DOI:

10.1177/0018726715578200hum. sagepub.com

Zhou, Min (2004)Revisiting Ethnic Entrepreneurship:Convergencies , Controversies, and Conceptzca I Advuncements'University of California, Los Angeles by the Center for Migration Studies of New Yotk. All tights reserved. 0197-9183/04/3803.0147 